\title{
PERFORMANCE OF LANDSCAPEING IRRIGATION SYSTEMS UNDER TREATED SEWAGE WATER CONDITIONS
}

\author{
Aboamera, M.A ${ }^{(1)}$
}

Gomaa, A.H ${ }^{(1)}$

Atta, Y.M.M(2)

\section{ABSTRACT}

The aim of this work was to compare the performance of sprinkler and subsurface trickle irrigation systems under treated sewage water increase of landscape conditions. Field experiments were conducted at Residential and Industrial Wastewater Treatment System located in the National Monitoring in Delta Barrage (El-Qanater), Cairo Egypt. Hybrid Bermuda grass was cultivated in two separate experimental locations; one was irrigated by treated sewage water and the other with Nile water. At each location three irrigation systems has been tested, which note (1) sprinkler irrigation system :a) rotary sprinkler heads and: b) spray sprinkler heads (2) subsurface trickle irrigation laterals with long path emitters and (3) irrigation with leaky pipes. Results indicated that, applying treated sewage water by subsurface trickle laterals was more safely used due to the lowest concentration of heavy metals in soil profile. The highest value of the volumetric soil moisture content $\left(0.152 \mathrm{~m}^{3}\right.$ of water $/ \mathrm{m}^{3}$ of soil) was recorded by subsurface trickle irrigation system with long path emitters when the treated sewage water is applied. Also, using subsurface trickle systems saved about $11 \%$ of total seasonal water applied comparing with sprinkler systems.

Key words: treated sewage water, irrigation, sprinkler, subsurface trickle, environmental impacts.

\section{INTRODUCTION}

carcity of water resources in Egypt dictated the need for using different types of low quality water. The reuse of drainage brackish water in Egypt is intensifying in order to compensate the increasing water demand.

(1) Associate professor, Agric. Eng. Dept. Faculty of Agric. Minufiya University.

(2) Researcher, Drainage Technology Div., Drainage research Institute, National Water Research Center. 
Due to the use of low quality water, irrigation needs to be managed with highly and effective conditions in order to prevent salt build up in soils with low natural salinity that effect on the crop yield and environment.Use of marginal quality water requires more complex management practices and more stringent monitoring than when good quality water is used (Pescod, 1992).

Martijin and Huibers (2001) reported that, pressurized irrigation methods that may be applicable with treated wastewater can be classified into localized irrigation (Drip and bubbler) and sprinkler irrigation (Gun sprinkler and center pivot).

Shelef (1977) pointed out that, the higher the level of treatment, the higher the quality of the effluent and consequently, its value. However, a more advanced treatment involves higher costs for construction, maintenance, operation and energy consumption, and the costs rise steeply with each advance in treatment level. Primary treatment removes coarse organic and inorganic solids, grease and oils from wastewater by screening settling and flotation processes. Secondary treatment involves both aerobic and anaerobic biological processes, in which organic matter in the wastewater is decomposed or oxidized by microorganisms. Tertiary treatment, employing chlorination micro screening or filtration, coagulation, precipitation and activated carbon adsorption, further removes suspended particles, biological oxygen demand BOD, nutrients, eutrophication factors and turbidity, and virtually eliminates residual pathogens. Quaternary or advanced treatment aims at upgrading the effluent to the level of fresh potable water and employs techniques such as ultra filtration, ion exchange, reverse osmosis, electro dialysis or distillation, by which any undesirable constituent including excess salinity can be removed from the water.

Asano (1998) reported that, for effluent sprinkler irrigation system, it is recommended to select low sprinklers with low pressure nozzles. However it recommended to irrigate during periods of low wind velocity and during hours when people are least expected in the vicinity of the irrigated field.. During hot weather, sprinkler irrigation, particularly when using high salinity water, may cause leaf burn. Hence irrigation at night when evaporation is low is preferable. 
El-Sayed (1997) showed that, the unpolluted water typically have $2 \mathrm{mg} / \mathrm{l}$ of Biological Oxygen Demand (BOD). Raw sewage has $600 \mathrm{mg} / \mathrm{l}$ of BOD, whereas the treated sewage effluents have BOD values ranged between 20 to $100 \mathrm{mg} / \mathrm{l}$ depending on the level of treatment. Chemical Oxygen Demand (COD) is widely used as a measure of the sensitivity to oxidation of the organic and inorganic materials, which are present in water bodies and effluent from sewage and industrial plants. The high (COD/BOD) ratio could be an indicator of presence of toxins. The ratio of sewage is usually about 2:1. The concentration of COD observed in surface water ranges from $20 \mathrm{mg} / \mathrm{l}$ or less in unpolluted water to greater than $200 \mathrm{mg} / \mathrm{l}$ in water receiving effluents.

Shuval et al (1986) suggested high levels of immunity against most viruses endemic in the community essentially block environmental transition by wastewater reuse (FAO1992). This basically depends the world health Organization WHO, (1989) guidelines but does not consider what happens when cultivated crops are exported outside of the community . Labeling of produce, to identify the quality of water used for its irrigation, is not common practice (after Shiekh et al 1998).

The objective of this research was to compare the performance of both sprinkler and subsurface trickle irrigation systems under treated sewage water for irrigating of landscape and their performance under Nile water. The comparison was concerned with crop water requirement, volumetric soil moisture content distribution, accumulation of salts in soil profile and environmental impacts due to applying treated sewage water on both the cultivated soil and the growing plant.

\section{MATERIALS AND METHODS}

Field experiments were carried out at Residential and Industrial Wastewater Treatment plant which located in the National Monitoring in Delta Barrage (El-Kanater), Cairo Egypt. The experimental area was planted by Hybrid Bermuda grass and divided into two main separate experiments; each was located at a separate site. First site was irrigated by treated sewage water and the second by Nile water. The area of each experiment was divided into four treatments and in each individual treatment, an irrigation system was constructed. Consequently, the 
differentiation between the performance of the three tested systems of irrigation either with Nile water or with treated sewage one will support the suitable irrigation system to be used with treated sewage water. The three irrigation systems has been tested, which note (1) sprinkler irrigation system :a) rotary sprinkler heads and (b) spray sprinkler heads (2) subsurface trickle irrigation laterals with long path emitters and (3) irrigation with leaky pipes

\section{Treatment plant}

Purification of sewage water passes through a number of treatment units which is so called treatment plant: and it deals with both industrial wastewater and domestic sewage effluent. The treatment plant includes two separate treatment units, one is chemical treatment unit and the other is treatment plant of sewage water.

The chemical treatment unit consists of the following components in arrange.

a) Equalization tank: used just to collect wastewater without sedimentation of contaminated chemicals,

b) Chemical mixing tank: the function of this tank is to collect wastewater to be injected with both chemical solutions and alkaline,

c) Settling tank: separate the periodical sedimentation from the wastewater,

d) Service tank: adjust the value of $\mathrm{pH}$ of wastewater and

e) Metoxy reactors: absorb heavy metals from wastewater.

The sewage treatment unit consists of the following components in arrange.

a. Receiving tank: used just to collect sewage water and industrial wastewater after passes in the chemical unit,

b. Bioxy biological tractors tower: the tower is constructed for biological oxidation,

c. Bioxy biological reactors: carrying out the interaction between the survivals bacteria which exist in the bioxy media and the mixed effluent,

d. Service tank: the water passes from the biological reactors to this tank to be pumped to the biofilter, 
e. Biofilter: the biofilter filled with bioxy media in small size to insure the biological filtration for the water pumped to the biofilter,

f. Chlorination: the water injected with chlorine solution after delivers from the biofilter and

g. De-chlorination: water pulled through two pumps after chlorination and passes to a carbon filter to reduce the concentration of chlorine in the water before delivered to the irrigation system.

Water pumped form the sewage treatment unit was treated and its chemical analysis was listed in Table (1) which represents the chemical analysis of untreated sewage water, treated sewage water and Nile water. The analysis was concerned with the contamination of physicochemical, major anions, and cations, microbiological parameters and the trace elements .

\section{Layout of the tested irrigation systems}

The total experimental area of the rotary sprinkler irrigation system was $900 \mathrm{~m}^{2}(30 \mathrm{~m} * 30 \mathrm{~m})$ and was $324 \mathrm{~m}^{2}(18 \mathrm{~m} * 18 \mathrm{~m})$ for the spray sprinkler irrigation system. For the subsurface system (long path emitters) and the irrigation with leaky system, each consists of eight laterals with $25 \mathrm{~m}$ long and spaced $50 \mathrm{~cm}$ apart. The laterals were provided by the required number of emitters at a distance of $25 \mathrm{~cm}$ and were buried at a depth of $20 \mathrm{~cm}$ beneath the soil surface. The value of the emission uniformity (EU) for the two systems was laboratory estimated and it was $96 \%$ for the long path emitters and was $97 \%$ for the leaky pipes laterals.

Figures (1 and 2) illustrate the tested field irrigation systems under treated sewage water delivered from the treatment plan and the Nile water. For both rotary and spray sprinkler irrigation equipments, the spacing between sprinkler heads was selected according to the value of Christiansen coefficient of uniformity (CU) based on the low quarter values of the collected water which was measured prior with sewage treated water and it was $84 \%$ for rotary sprinkler head and $80 \%$ for spray sprinkler heads at $200 \mathrm{kPa}$ of the operating pressure. This was obtained with an overlapping percent of $65 \%$ for the two sprinkler heads. The calculated spacing between sprinkler heads in case of rotary sprinkler irrigation system was $10 \mathrm{~m}$ and also was $10 \mathrm{~m}$ between laterals; hence the sprinkler heads were arranged in square vertices. In case of spray 
sprinkler irrigation system, the spacing between sprinkler heads and lateral lines was $6 \mathrm{~m}$.

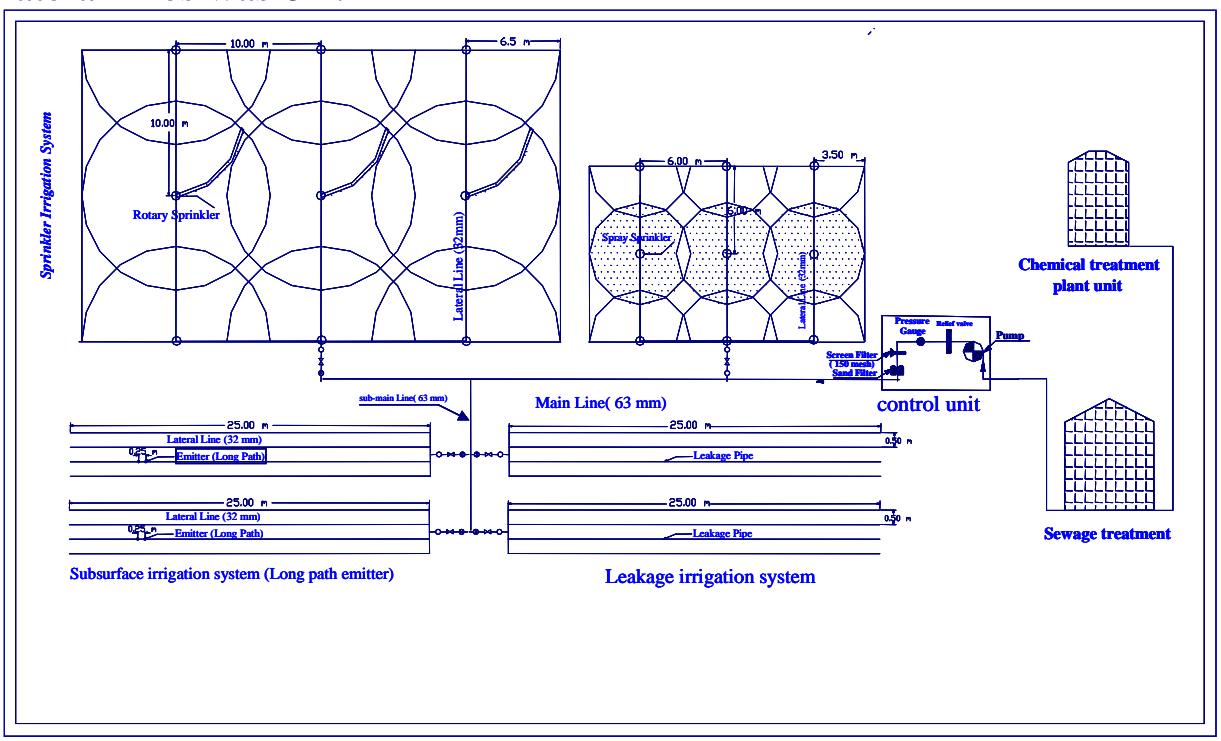

Figure (1): Experimental irrigation systems irrigated under treated sewage water.

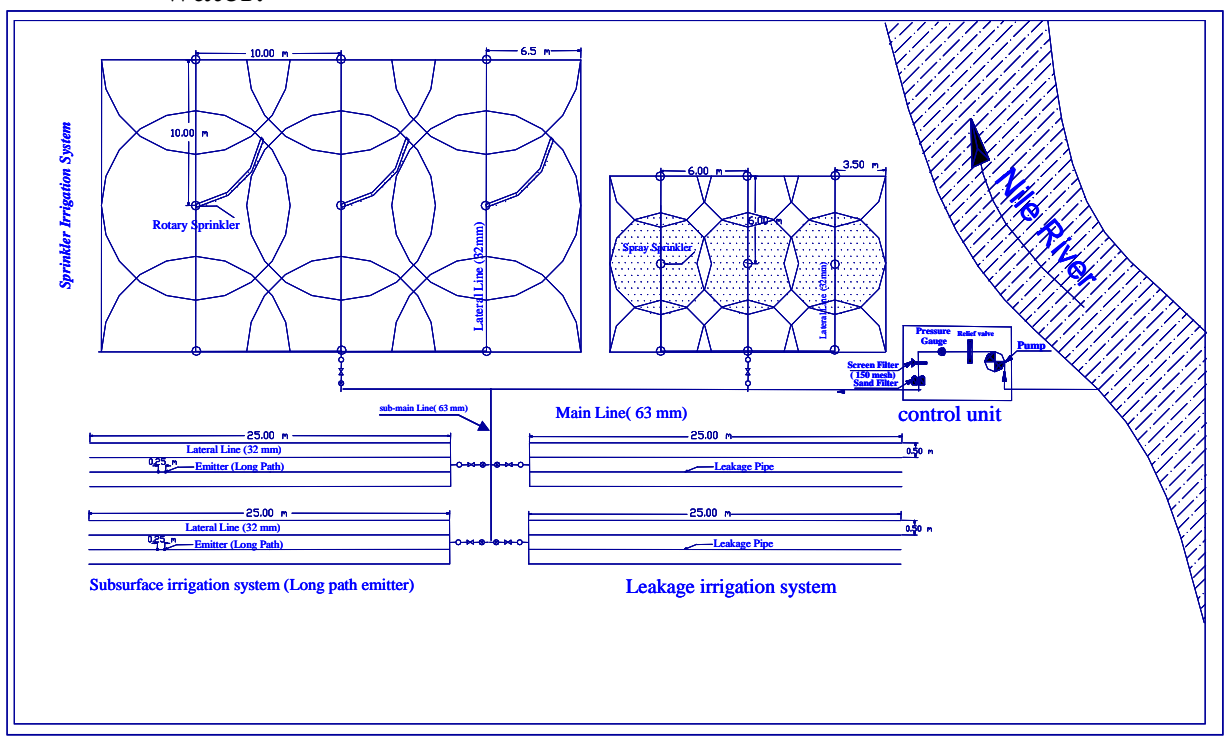

Figure (2): Field experimental irrigation systems under Nile water. 


\section{Table(1):Chemical analysis of untreated sewage water, treated sewage water and Nile water.}

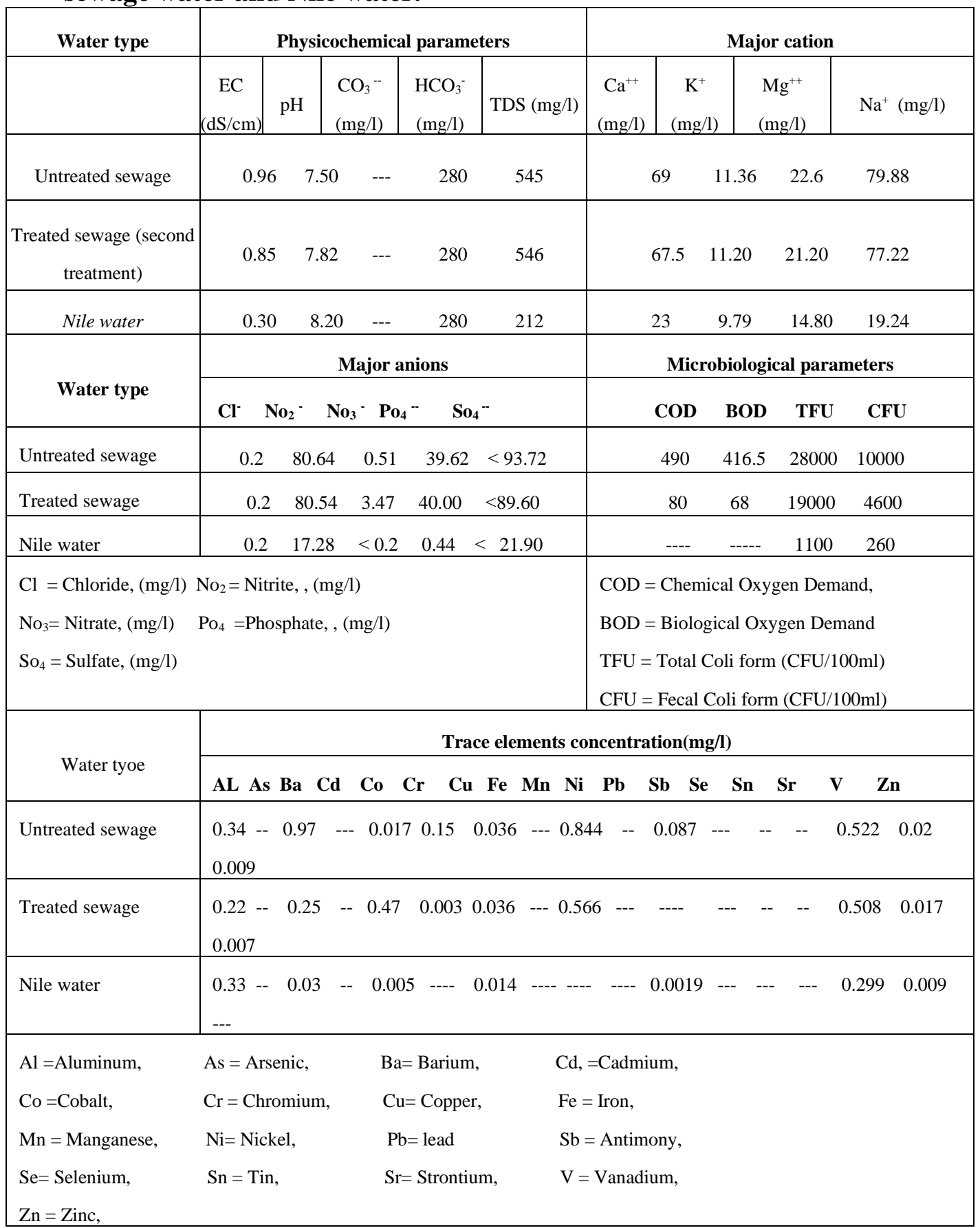




\section{Calculations of the crop water requirements and field water supply.}

The CROPWAT program based on windows version 4.3 (FAO 1998), which uses Penman-Monteith method for calculating the reference evapotranspiration $\left(\mathrm{ET}_{0}\right)$ and published by FAO (1992), was used for estimating the daily crop water requirement and field water supply. The program uses a flexible menu system and file handling with extensive use of graphics. Graphics of the input data (climate and cropping pattern) and the output results (crop water requirement, and soil moisture deficit) can be drown and printed with ease.

\section{Detection of Soil and plant analysis chemical concentration.}

The concentration of soluble cations and anions in soil sample were determined in the extract of the soil sample with ratio 1:2.5 of soil to water. The cations were determined using Inductively Coupled Plasma (ICP) and the anions were determined using Ion Chromatography (IC).

Major anions such as chloride $(\mathrm{Cl})$, nitrite $\left(\mathrm{NO}_{2}\right)$, nitrates $\left(\mathrm{NO}_{3}\right)$, phosphate $\left(\mathrm{PO}_{4}\right)$ and Sulphate $\left(\mathrm{SO}_{4}\right)$ were determined using Ion Chromatography (IC). While Carbonate $\left(\mathrm{CO}_{3}\right)$ and bicarbonate $\left(\mathrm{HCO}_{3}\right)$ were determined by titration method using 0.02 of $\mathrm{NH}_{2} \mathrm{CO}_{3}$ with phenolphthalein and methyl orange as indicators.

Major cations such as boron (b), calcium (Ca), potassium (K), magnesium $(\mathrm{Mg})$ and sodium $(\mathrm{Na})$ in addition to heavy metals such as Arsenic (As), chromium $(\mathrm{Cr})$, copper $(\mathrm{Cu})$, iron $(\mathrm{Fe})$, nickel $(\mathrm{Ni})$, lead $(\mathrm{Pb})$ and zinc (Zn) were determined using the Inductively Coupled Plasma - Emission spectrometry (ICP - ES) with Ultra Sonic Nobulizer (USN). This Nebulizer decrease the instrumental detection limits by $10 \%$. Soil sample were filtered by filtration system through membrane filter of pore size 0.45 micrometer before analysis.

As mentioned, before the analysis of plant samples was carried out for measuring total coliform density (TCD) and fecal coliform density (FCD) in addition to measuring the concentration of heavy metals in both leaves roots. Total coliform density (TCD) and fecal coliform density (FCD) were determined using membrane filter technique according to standard method No.9222B (APHA, 1992). Both TCD and FCD were measured in $100 \mathrm{ml}$ of filtered sample. 


\section{RESULTS AND DISCUSSION}

\section{Crop water requirement $(\mathrm{ETc})$, crop coefficient $(\mathrm{Kc})$ and field water supply (FWS)}

Figure (3) represents the trend of monthly changing of the output results of CROP WAT program, which is field water supply (FWS), crop evapotranspiration (ETc), and the crop coefficient $(\mathrm{Kc})$ in addition to the reference evapotranspiraion $\left(\mathrm{ET}_{0}\right)$ recorded at each experimental location. The value of field water supply for the four tested systems of irrigation depended upon the measured value of the irrigation application efficiency of the system (Ea). The measured application efficiency for sprinkler irrigation systems was $80 \%$ with both rotary and spray sprinkler heads, and was $90 \%$ for the subsurface trickle irrigation system with long path emitters and also for irrigation with leaky pipes. The data presented in figure (3) showed that, the peak monthly field water supply (FWS) was $211.41 \mathrm{~mm} /$ month observed with sprinkler irrigation systems in July, the lowest was $35.31 \mathrm{~mm} /$ month observed with subsurface trickle system and leaky pipes laterals in December. The trend of changing the value of crop coefficient $(\mathrm{Kc})$ reflects the four known growing stages of Bermuda grass; (initial stage, crop development, mid-season and harvesting), however the average value of $(\mathrm{Kc})$ for each stage was not greatly changed. The figure also showed that, the monthly plant water requirement $(\mathrm{ETc})$ was less than the monthly required field water supply (FWS) for the three systems of irrigation. This obviously was due to the higher average monthly value of crop coefficient $(\mathrm{Kc})$ for Bermuda grass. The results represented in Fig. (3) was calculated and plotted according to the value of monthly reference Evapotranspiration $\left(\mathrm{ET}_{0}\right)$ which obtain form CROPWAT program version 4.3 (1998) as mentioned before.

The total seasonal field water supply per fedden was $1354 \mathrm{~mm}$ with subsurface trickle system and leaky pipes laterals, while it was $1523 \mathrm{~mm}$ for the two tested sprinkler head. Therefore, applying the irrigation water (Nile or treated sewage) by subsurface trickle system will save a remarkable amount of seasonal water requirements (about 170 $\mathrm{mm} / \mathrm{season}$ ) which represents about $11 \%$ of total seasonal water applied 


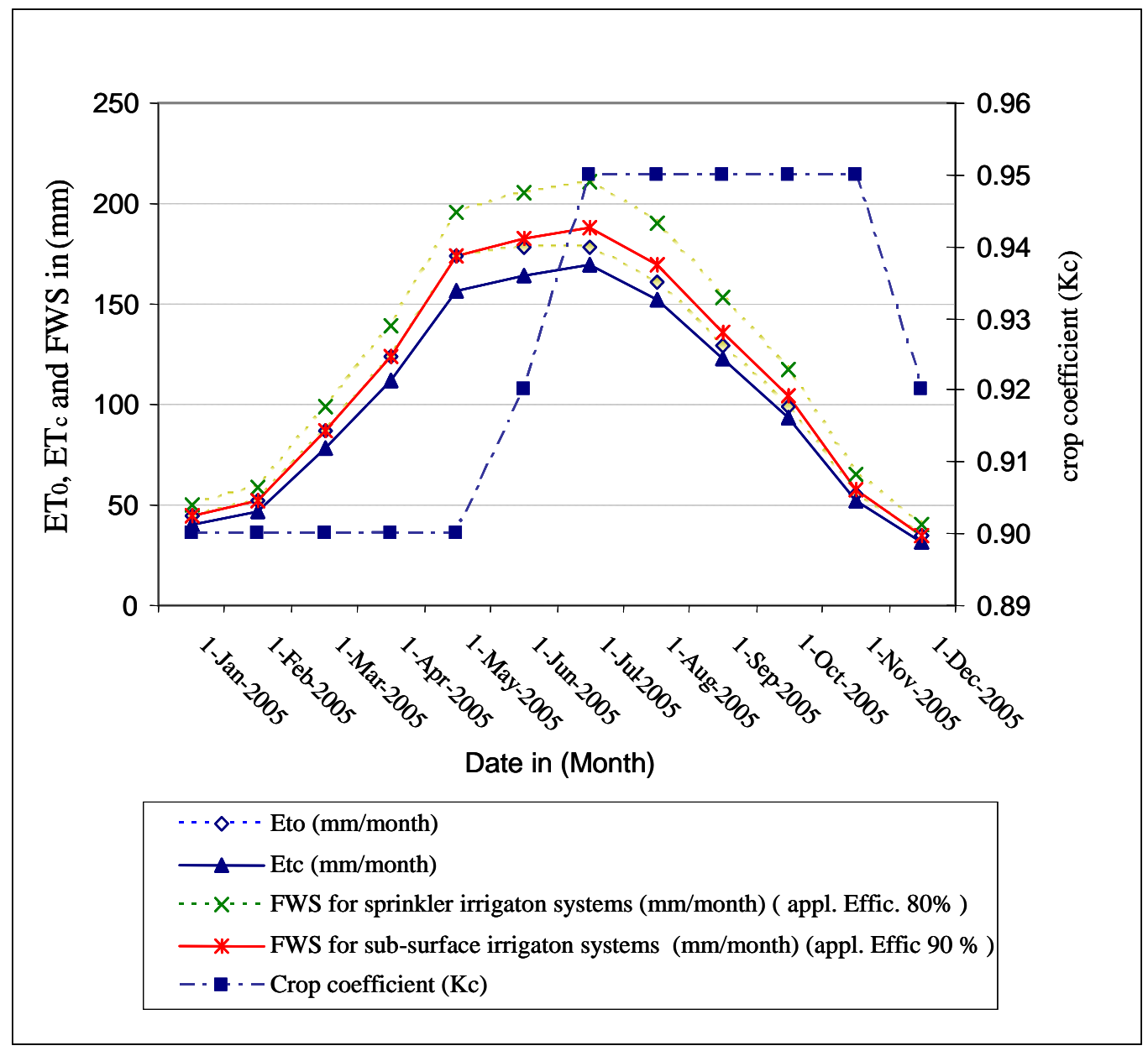

Figure (3): Average monthly evapotranspiration $\left(\mathrm{ET}_{0}\right)$, plant evapotranspiration (ETc) and flied water supply (FWS) recorded along the growing season of Bermuda grass

\section{Volumetric soil moisture content distribution}

The volumetric soil moisture content decreased with soil depth after 2 hours from irrigation for the sprinkler systems (rotary and spray heads) and the two types of irrigation water (Nile and treated sewage) as presented in table (2). However, after 48 and 72 hours, it increased at a depth of $30 \mathrm{~cm}$ and then decreased at a depth of $50 \mathrm{~cm}$ with the treated sewage water and the two tested sprinkler heads. For the two types of water applied, the volumetric soil moisture content decreased with time 
for all soil layers. After three days from irrigation with rotary sprinkler head, the highest average volumetric soil moisture content $\left(0.113 \mathrm{~m}^{3}\right.$ water $/ \mathrm{m}^{3}$ of soil) was observed with the treated sewage While the lowest value was $\left(0.104 \mathrm{~m}^{3}\right.$ water $/ \mathrm{m}^{3}$ of soil) with Nile with spray sprinkler head. This may be due to the best uniform distribution of water produced by rotary heads

Table (2): Volumetric soil moisture content in $\left(\mathrm{m}^{3}\right.$ of water $/ \mathrm{m}^{3}$ of soil) with soil depth for sprinkler irrigation system (rotary and spary) after different times from irrigation.

\begin{tabular}{|c|c|c|c|c|c|c|c|c|c|c|c|c|}
\hline \multirow{5}{*}{ Soil depth $(\mathrm{cm})$} & \multicolumn{12}{|c|}{ Volumetric Soil moisture content $\left(\mathrm{m}^{3}\right.$ of water $/ \mathrm{m}^{3}$ of soil) } \\
\hline & \multicolumn{6}{|c|}{ rotary sprinkler head } & \multicolumn{6}{|c|}{ spray sprinkler head } \\
\hline & \multicolumn{3}{|c|}{ Nile water } & \multicolumn{3}{|c|}{$\begin{array}{c}\text { Treated sewage } \\
\text { water } \\
\end{array}$} & \multicolumn{3}{|c|}{ Nile water } & \multicolumn{3}{|c|}{$\begin{array}{c}\text { Treated sewage } \\
\text { water } \\
\end{array}$} \\
\hline & \multicolumn{3}{|c|}{$\begin{array}{c}\text { Time after } \\
\text { irrigation (hr) }\end{array}$} & \multicolumn{3}{|c|}{$\begin{array}{c}\text { Time after } \\
\text { irrigation (hr) }\end{array}$} & \multicolumn{3}{|c|}{$\begin{array}{c}\text { Time after } \\
\text { irrigation (hr) }\end{array}$} & \multicolumn{3}{|c|}{$\begin{array}{c}\text { Time after } \\
\text { irrigation (hr) }\end{array}$} \\
\hline & 2 & 48 & 72 & 2 & 48 & 72 & 2 & 48 & 72 & 2 & 48 & 72 \\
\hline $0-20$ & 0.148 & 0.108 & 0.100 & 0.144 & 0.116 & 0.104 & 0.128 & 0.122 & 0.104 & 0.136 & 0.122 & 0.104 \\
\hline $20-40$ & 0.136 & 0.128 & 0.124 & 0.128 & 0.128 & 0.124 & 0.124 & 0.120 & 0.116 & 0.128 & 0.120 & 0.116 \\
\hline $40-60$ & 0.112 & 0.108 & 0.104 & 0.120 & 0.116 & 0.112 & 0.096 & 0.092 & 0.092 & 0.116 & 0.116 & 0.112 \\
\hline Average & 0.132 & 0.115 & 0.109 & 0.131 & 0.120 & 0.113 & 0.116 & 0.111 & 0.104 & 0.127 & 0.119 & 0.110 \\
\hline
\end{tabular}

Table (3) represents the variation of volumetric soil moisture content with soil depth for the subsurface trickle irrigation system and leaky pipes laterals. For all treatments, the volumetric soil moisture content decreased with the elapsed time from irrigation application at the three depths of soil profile. The highest values of volumetric soil moisture content were recorded by the treated sewage water for the two systems. The highest average value $0.14 \mathrm{~m}^{3}$ water $/ \mathrm{m}^{3}$ of soil) was observed with the treated sewage water when it applied by subsurface trickle laterals with long bath emitters. While the lowest $\left(0.101 \mathrm{~m}^{3}\right.$ of water $/ \mathrm{m}^{3}$ of soil $)$ was observed with Nile water when it applied by the same system. Leaky pipes laterals produce a higher average volumetric soil moisture content comparing 
with long path emitters. This may be due the sufficient of water which stripped horizontally with soil layers occurred by leaky pips laterals

Table (3): Volumetric soil moisture content in $\left(\mathrm{m}^{3}\right.$ water $/ \mathrm{m}^{3}$ of soil) with soil depth for leaky pipes laterals and subsurface trickle with longpath emitters.

\begin{tabular}{|c|c|c|c|c|c|c|c|c|c|c|c|c|}
\hline \multirow{5}{*}{ Soil depth $(\mathrm{cm})$} & \multicolumn{12}{|c|}{ Volumetric Soil moisture content $\left(\mathrm{m}^{3}\right.$ water $/ \mathrm{m}^{3}$ soil) } \\
\hline & \multicolumn{6}{|c|}{ leaky pipes laterals } & \multicolumn{6}{|c|}{ Long path emitters } \\
\hline & \multicolumn{3}{|c|}{ Nile water } & \multicolumn{3}{|c|}{$\begin{array}{c}\text { Treated sewage } \\
\text { water }\end{array}$} & \multicolumn{3}{|c|}{ Nile water } & \multicolumn{3}{|c|}{$\begin{array}{c}\text { Treated sewage } \\
\text { water }\end{array}$} \\
\hline & \multicolumn{3}{|c|}{$\begin{array}{c}\text { Time after } \\
\text { irrigation (hr) }\end{array}$} & \multicolumn{3}{|c|}{$\begin{array}{c}\text { Time after } \\
\text { irrigation (hr) }\end{array}$} & \multicolumn{3}{|c|}{$\begin{array}{c}\text { Time after } \\
\text { irrigation (hr) }\end{array}$} & \multicolumn{3}{|c|}{$\begin{array}{c}\text { Time after } \\
\text { irrigation (hr) }\end{array}$} \\
\hline & 2 & 48 & 72 & 2 & 48 & 72 & 2 & 48 & 72 & 2 & 48 & 72 \\
\hline $0-20$ & 0.128 & 0.104 & 0.092 & 0.132 & 0.108 & 0.096 & 0.128 & 0.104 & 0.092 & 0.124 & 0.108 & 0.096 \\
\hline $20-40$ & 0.144 & 0.120 & 0.112 & 0.148 & 0.120 & 0.112 & 0.144 & 0.112 & 0.104 & 0.144 & 0.116 & 0.108 \\
\hline $40-60$ & 0.136 & 0.120 & 0.112 & 0.144 & 0.124 & 0.116 & 0.144 & 0.116 & 0.108 & 0.152 & 0.120 & 0.112 \\
\hline Average. & 0.136 & 0.115 & 0.105 & 0.141 & 0.117 & 0.108 & 0.139 & 0.111 & 0.101 & 0.140 & 0.115 & 0.105 \\
\hline
\end{tabular}

\section{Statistical coefficient of variation of the volumetric soil moisture content}

The statistical coefficient of variation (CV) of the volumetric soil moisture content is the ratio between the standard deviation of the sample and the mean value of this sample. Therefore, it can be computed for shallow depths up to $10 \mathrm{~cm}$ and also for deeper depth greater than or equal to $50 \mathrm{~cm}$. Table (4) represents the different values of the statistical coefficient of variation of soil moisture content and its changes with both the elapsed time from irrigation application and the type of irrigation water applied. Irrigation system operated with leaky pipes laterals gave the lower coefficient of variation of soil moisture content when the treated sewage water is applied $(0.80 \%)$ after 2 hours from irrigation application at the shallow soil depths. The lower values of statistical coefficient of variation indicate more stability of soil moisture content. The highest value of CV (23.60\%) was obtained at the deeper depth with sprinkler irrigation system with rotary sprinkler heads when the treated sewage water is applied. While the lowest value $(0.3 \%)$ was observed 
with leaky pipes laterals when the treated sewage water is applied after three days from irrigation application. Irrigation system with leaky pipes kept the stability of soil moisture content either in shallow depth or deeper depth, where the coefficient of variation $(\mathrm{CV})$ remains at lower value comparing with the other systems when the treated sewage water is applied. The presented results in table (4) also showed that, at any system of irrigation, the treated sewage water resulted more stability of soil moisture content than Nile water. This occurred at the three elapsed times from irrigation application except with subsurface trickle irrigation system with long path emitters after 2 and $72 \mathrm{hrs}$ from irrigation application in shallow soil depths.

Table (4): Statistical coefficient of variation of the volumetric soil moisture content $(\mathrm{CV})$ and its change with elapsed time from irrigation and the applied water.

\begin{tabular}{|c|c|c|c|c|c|c|c|c|c|c|c|c|c|}
\hline \multirow{3}{*}{$\begin{array}{c}\text { Irrigation } \\
\text { system }\end{array}$} & \multirow{3}{*}{$\begin{array}{c}\text { Type of } \\
\text { water } \\
\text { applied }\end{array}$} & \multicolumn{12}{|c|}{ Elapsed time from irrigation } \\
\hline & & \multicolumn{4}{|c|}{2 hours } & \multicolumn{4}{|c|}{48 hours } & \multicolumn{4}{|c|}{72 hours } \\
\hline & & SVM & $\begin{array}{l}\mathrm{CV} \\
(\%) \\
\end{array}$ & DVM & $\begin{array}{l}\mathrm{CV} \\
(\%)\end{array}$ & SVM & $\begin{array}{l}\mathrm{CV} \\
(\%) \\
\end{array}$ & DVM & $\begin{array}{l}\mathrm{CV} \\
(\%)\end{array}$ & SVM & $\begin{array}{l}\mathrm{CV} \\
(\%) \\
\end{array}$ & DVM & $\begin{array}{l}\mathrm{CV} \\
(\%)\end{array}$ \\
\hline \multirow{2}{*}{$\begin{array}{l}\text { Sprinkler } \\
\text { (rotary) }\end{array}$} & Nile & 0.148 & 6.60 & 0.122 & 10.6 & 0.108 & 7.10 & 0.108 & 7.4 & 0.100 & 10.2 & 0.104 & 0.50 \\
\hline & $\begin{array}{l}\text { Treated } \\
\text { sewage }\end{array}$ & 0.144 & 1.30 & 0.120 & 3.6 & 0.116 & 5.00 & 0.116 & 3.7 & 0.104 & 1.7 & 0.112 & 3.40 \\
\hline \multirow{2}{*}{$\begin{array}{c}\text { Sprinkler } \\
\text { ( spray) }\end{array}$} & Nile & 0.128 & 12.6 & 0.096 & 23.6 & 0.112 & 4.80 & 0.092 & 5.9 & 0.104 & 4.8 & 0.092 & 3.40 \\
\hline & $\begin{array}{l}\text { Treated } \\
\text { sewage }\end{array}$ & 0.136 & 2.60 & 0.116 & 2.1 & 0.112 & 2.40 & 0.116 & 1.1 & 0.104 & 2.1 & 0.116 & 1.10 \\
\hline \multirow{2}{*}{$\begin{array}{c}\text { (leaky pipe) } \\
\text { laterals }\end{array}$} & Nile & 0.128 & 0.90 & 0.136 & 1.7 & 0.104 & 1.60 & 0.120 & 1.5 & 0.092 & 0.9 & 0.112 & 0.30 \\
\hline & $\begin{array}{l}\text { Treated } \\
\text { sewage }\end{array}$ & 0.132 & 0.80 & 0.144 & 3.3 & 0.108 & 0.20 & 0.124 & 0.7 & 0.096 & 0.3 & 0.116 & 0.60 \\
\hline \multirow{2}{*}{$\begin{array}{l}\text { Subsurface } \\
\text { (long path } \\
\text { emitters) }\end{array}$} & Nile & 0.128 & 1.10 & 0.144 & 2.3 & 0.104 & 0.50 & 0.116 & 1.7 & 0.092 & 0.5 & 0.108 & 2.30 \\
\hline & $\begin{array}{l}\text { Treated } \\
\text { sewage }\end{array}$ & 0.124 & 1.80 & 0.152 & 0.4 & 0.108 & 0.50 & 0.120 & 1.8 & 0.096 & 0.4 & 0.112 & 1.80 \\
\hline
\end{tabular}

*SVM= Shallow volumetric moisture $\left(\mathrm{m}^{3}\right.$ water $/ \mathrm{m}^{3}$ of soil

*DVM= deep volumetric moisture $\left(\mathrm{m}^{3}\right.$ water $/ \mathrm{m}^{3}$ of soil 


\section{Accumulation of salts in soil profile}

Figure (4) illustrates the variation of the average value of electrical conductivity (EC) in $\mathrm{dS} / \mathrm{m}$ with soil depth for all the tested treatments. It showed that, applying treated sewage water produced higher values of EC in soil surface layers with all the used irrigation systems. In contrast, with Nile water, the accumulation of salts decreased with time where the average value of EC reached to its lowest value $(0.85 \mathrm{ds} / \mathrm{m})$ at a depth of $10 \mathrm{~cm}$ of soil layer with all tested systems . Applying treated sewage water with sprinkler irrigation systems (rotary and spray heads)led to increasing the accumulation of salts with time. At the end of the growing season the salts accumulates sharply specially at the soil surface layers and it reaches $1.5 \mathrm{dS} / \mathrm{m}$ at a depth of $10 \mathrm{~cm}$ for the two sprinkler heads The least accumulation of salts at the end of the growing season was observed with Nile water under subsurface trickle with long path emitters and leaky pipes laterals. The value of EC reached to $1 \mathrm{dS} / \mathrm{m}$ with leaky pipes laterals and to $0.9 \mathrm{dS} / \mathrm{m}$ with long path emitters. With treated sewage water, the salts accumulate slightly from the beginning to the end of the growing season, where the value of EC reached to $1.3 \mathrm{dS} / \mathrm{m}$ with leaky pipes laterals while it remains constant at $1.2 \mathrm{dS} / \mathrm{m}$ for subsurface trickle with long path emitters. It also evident that, subsurface trickle irrigation system with long path emitters help in decreasing the accumulation of salts more than sprinkler systems. This may be due to the sufficient of water in soil profile that achieved with subsurface trickle irrigation system.

\section{Environmental impacts due to applying treated sewage water}

Reuse of the treated sewage water, as a new source of irrigation water will be accompanied with a number of environmental impacts on soil, plant and consequently on human body. Environmental impacts either in the cultivated soil or in the growing plant basically focused upon the change of the concentration of the existed heavy metals due to applying the treated sewage water.

\section{(a)Impacts on the cultivated soil}

Table (5) represents the average concentration of heavy metals in soil after applying treated sewage water and the standard concentration reported by World Health Organization WHO 1995 for each metal. It 
showed that, the concentration of some heavy metals, such as Cobalt, Chromium, Copper, Nickel and lead was lower than the standard values for all the tested systems. It also showed that, the concentration of some metals varied according to the used system of irrigation. Some metals such as Aluminum, Iron and Manganese existed in extremely higher concentration and varied slightly due to the used system of irrigation. Subsurface trickle irrigation with long path emitters caused a reduction in the concentration of Aluminum, Iron Manganese, Nickle and lead compared with the other tested systems. Therefore it can be concluded that applying treated sewage water by subsurface trickle system with long path emitter may be more safely than the sprinkler irrigation system for the irrigation of landscape. This was due to the lowest concentrations of heavy metals recorded by the both subsurface trickle system with long path emitters and leaky pips laterals compared with the two sprinkler heads. 


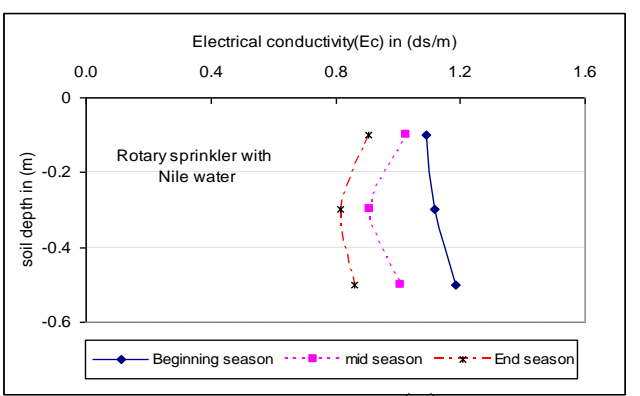

(a)

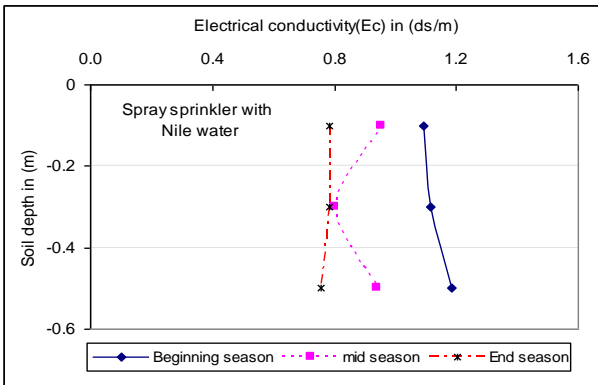

(c)

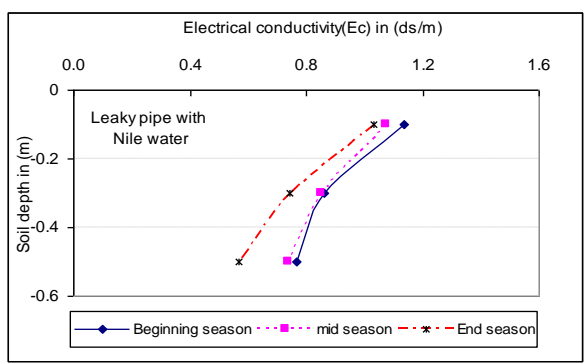

(e)

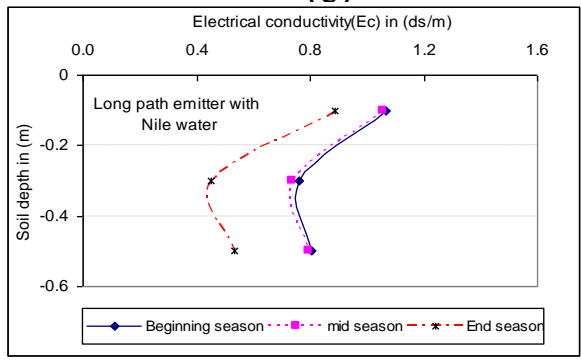

(g)

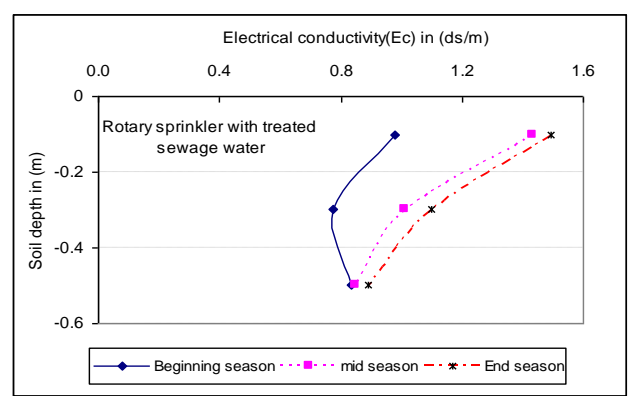

(b)

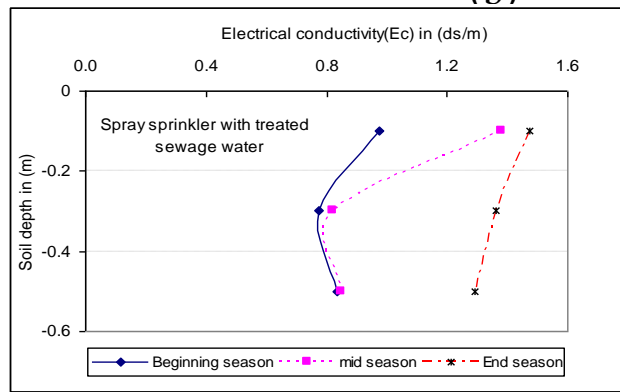

(d)

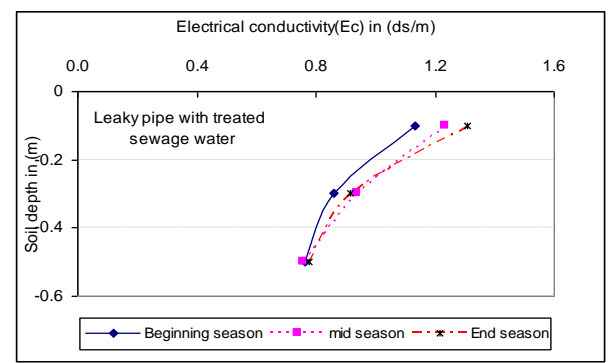

(f)

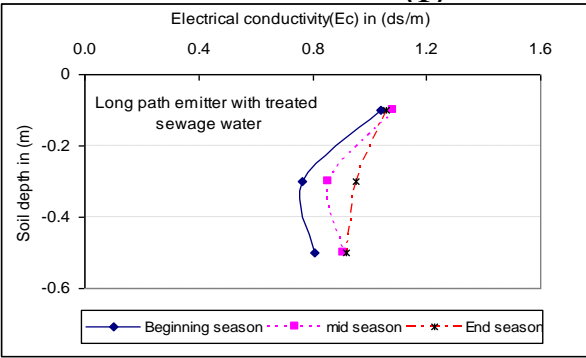

(h)

Figure (4): Average electrical conductivity (EC) with soil depth recorded at stage three different stage along the growing season for both Nile and treated sewage water.

a- rotary sprinkler with Nile water

c- spray sprinkler with Nile water

e- leaky pipe with Nile water

g- long path emitter with Nile water b- rotary sprinkler with treated sewage water

d- spray sprinkler with treated sewage water

f- leaky pipe with treated sewage water

$\mathrm{h}$ - long path emitter with treated sewage water 


\section{(b) Impacts on the growing plant}

Concentrations of 17 heavy metals were measured two times in both leaves and roots of Bermuda grass. One was before applying the irrigation water and the other was at the end of the growing season. The obtained data were listed in table (6). The concentration of each individual metal in both leaves and roots increased at the end of the growing season for the two types of the irrigation water except the concentration of Chromium, Iron and Nickel where it decreased sharply especially in roots.

Lead is considered as the most harmful element which causes dangerous diseases if its concentration was high. The presented data in table (6) also showed that, the changing percent of the concentration of lead in roots were $120 \%$ and zero\% in case of applying Nile water and treated sewage water respectively. While it was $400 \%$ and $540 \%$ in leaves with Nile and treated sewage water, respectively.

Table (5): Average concentrations of some heavy metals in soil profile irrigated by treated sewage water $(\mathrm{mg} / \mathrm{kg})$ and the standard values reported by World Health Organization (WHO, 1995).

\begin{tabular}{|c|c|c|c|c|c|}
\hline \multirow[b]{2}{*}{ Element } & \multirow[b]{2}{*}{$\begin{array}{c}\text { standard concentration } \\
\text { reported } \\
\text { by (WHO1995) }\end{array}$} & \multicolumn{4}{|c|}{ Average concentration of heavy metal $(\mathrm{mg} / \mathrm{kg})$ in soil sample irrigated by treated sewage water } \\
\hline & & $\begin{array}{c}\text { average concentration } \\
\text { recorded with sprinkle } \\
\text { system (rotary) }\end{array}$ & $\begin{array}{c}\text { average concentration } \\
\text { recorded with sprinkler } \\
\text { system (spray) }\end{array}$ & $\begin{array}{c}\text { average concentration } \\
\text { recorded with (leaky } \\
\text { pipes laterals) }\end{array}$ & $\begin{array}{l}\text { average concentration } \\
\text { recorded with Subsurface } \\
\text { trickle (long path emitters) }\end{array}$ \\
\hline Aluminum, Al. & ----- & 43991.70 & 42578.30 & 47766.70 & 42041.70 \\
\hline Barium, Ba. & 290 & 306.90 & 324.00 & 400.50 & 297.70 \\
\hline Cadmium,Cd. & 7 & 16.00 & 15.40 & 13.10 & 14.10 \\
\hline Cobalt, Co. & 50 & 27.80 & 24.00 & 32.60 & 26.20 \\
\hline Chromium,Cr. & 3200 & 87.70 & 91.30 & 142.30 & 105.40 \\
\hline Copper, Cu. & 140 & 60.30 & 63.20 & 82.90 & 90.00 \\
\hline Iron, $\mathrm{Fe}$. & 300 & 40625.00 & 40766.70 & 50608.30 & 38150.00 \\
\hline Manganese,Mn & 100 & 815.80 & 769.30 & 996.80 & 693.50 \\
\hline Nickel, Ni. & 850 & 91.30 & 89.50 & 91.70 & 73.00 \\
\hline Lead, $\mathrm{Pb}$. & 150 & 38.90 & 41.10 & 53.30 & 38.40 \\
\hline Strontium, Sr. & ----- & 175.10 & 172.20 & 219.60 & 198.10 \\
\hline Zinc,Zn. & 200 & 149.00 & 130.00 & 145.50 & 246.20 \\
\hline
\end{tabular}


Table (6) also showed that, there were some metals which its concentration was increased sharply at the end of the growing season in both roots and leaves. These metals were Aluminum, Barium, Molybdenum and Strontium and this was occurred with both Nile and sewage water. The concentration of heavy metals in leaves and roots did not depend upon the used system of irrigation. It affected only by the quality of the irrigation water. With treated sewage water some metals decreased sharply such as Cadmium, Chromium, Iron and Neckline in both leaves and roots. Others increased sharply such as Aluminum, Barium, Molybdenum and Strontium, therefore, applying treated sewage water might be carried out with care.

Table (6): Average concentrations of some heavy metals in both leaves and roots of Bermuda plant $(\mathrm{mg} / \mathrm{kg})$ before and after applying both Nile and treated sewage water.

\begin{tabular}{|c|c|c|c|c|c|c|c|c|c|c|}
\hline \multirow{4}{*}{ Elements } & \multicolumn{10}{|c|}{ Average concentration of heavy metal $(\mathrm{mg} / \mathrm{kg})$ at the end of the growing season. } \\
\hline & \multirow{2}{*}{\multicolumn{2}{|c|}{$\begin{array}{c}\text { Concentration of } \\
\text { heavy metals } \\
\text { before applying } \\
\text { irrigation water } \\
\quad(\mathrm{mg} / \mathrm{kg})\end{array}$}} & \multicolumn{2}{|c|}{$\begin{array}{l}\text { Concentration of } \\
\text { heavy metals at } \\
\text { the end of the } \\
\text { growing season } \\
\quad(\mathrm{mg} / \mathrm{kg})\end{array}$} & \multirow{2}{*}{\multicolumn{2}{|c|}{$\begin{array}{c}\text { Changing } \\
\text { percent }(\%)\end{array}$}} & \multicolumn{2}{|c|}{$\begin{array}{l}\text { Concentration of } \\
\text { heavy metals at the } \\
\text { end of the growing } \\
\text { season }(\mathrm{mg} / \mathrm{kg})\end{array}$} & \multirow{2}{*}{\multicolumn{2}{|c|}{$\begin{array}{l}\text { Changing } \\
\text { percent }(\%)\end{array}$}} \\
\hline & & & \multicolumn{2}{|c|}{ Nile water } & & & \multicolumn{2}{|c|}{$\begin{array}{c}\text { Treated sewage } \\
\text { water } \\
\end{array}$} & & \\
\hline & Leaves & Roots & Leaves & Roots & Leaves & Roots & Leaves & Roots & Leaves & Roots \\
\hline Aluminum, Al. & $<2$ & $<2$ & 758 & 290 & 37800 & 14400 & 448 & 242 & 22300 & 12000 \\
\hline Arsenic, As. & $<2$ & $<2$ & $<2$ & $<2$ & 0.00 & 0.00 & $<2$ & $<2$ & 0.00 & 0.00 \\
\hline Barium, Ba. & $<1$ & $<1$ & 18 & 15 & 1700 & 1400 & 13.60 & 20.00 & 1260 & 1900 \\
\hline Cadmium,Cd. & 1.20 & 0.40 & 1.20 & 0.60 & 0.00 & 50 & $<0.10$ & $<0.10$ & -91.67 & -75.00 \\
\hline Cobalt, Co. & $<1$ & $<1$ & 2.00 & $<1$ & 100 & 0.00 & 2.20 & $<1$ & 120.00 & 0.00 \\
\hline Chromium,Cr. & 63.00 & 59.60 & $<0.40$ & $<0.40$ & -99.37 & -99.33 & $<0.40$ & $<0.40$ & -99.37 & -99.33 \\
\hline Copper, $\mathrm{Cu}$. & 20.60 & 12.60 & 30.40 & 19.60 & 47.57 & 55.56 & 23.00 & 13.60 & 11.65 & 7.94 \\
\hline Iron, Fe. & 982 & 640 & 980 & 420 & -0.20 & -34.38 & 546 & 344 & -44.40 & -46.25 \\
\hline Manganese,Mn & 21.40 & 76.00 & 68.00 & 40.00 & 217.76 & -47.37 & 73.20 & 63.60 & 242.06 & -16.32 \\
\hline
\end{tabular}




\begin{tabular}{|l|c|c|c|c|c|c|c|c|c|c|}
\hline Molybdenum & $<2$ & $<2$ & 634 & 426 & 31600 & 21200 & 446 & 682 & 22200 & 34000 \\
\hline Nickel, Ni. & 50.60 & 51.60 & 1.60 & 1.20 & -96.84 & -97.67 & 2.40 & 4.00 & -95.26 & -92.25 \\
\hline Lead, Pb. & $<1$ & $<1$ & 5.00 & 2.20 & 400 & 120 & 6.40 & $<1$ & 540.00 & 0.00 \\
\hline Selenium,Se. & $<6$ & $<6$ & $<6$ & $<6$ & 0.00 & 0.00 & $<6$ & $<6$ & 0.00 & 0.00 \\
\hline Tin, Sn & $<6$ & $<6$ & $<6$ & $<6$ & 0.00 & 0.00 & $<6$ & $<6$ & 0.00 & 0.00 \\
\hline Strontium, Sr. & $<1$ & $<1$ & 30.40 & 28.00 & 2940 & 2700 & 18.20 & 23.20 & 1720 & 2220 \\
\hline Vanadium, V. & $<1$ & $<1$ & $<1$ & $<1$ & 0.00 & 0.00 & $<1$ & $<1$ & 0.00 & 0.00 \\
\hline Zinc,Zn. & 50.50 & 36.20 & 67.40 & 44.80 & 33.47 & 23.76 & 86.00 & 52.00 & 70.30 & 43.65 \\
\hline
\end{tabular}

Table (7) represents the total fical density (TCD) and fecal coliform count (FCC) on Bermuda leaves before and after applying treated sewage and Nile water At the end of the growing season, the total fecal coliform density increased by $900 \%$ with treated sewage water, while it increased only by $10.13 \%$ when the Nile water was applied. As for the count of fecal coliform, it increased by $900 \%$ with treated sewage water, while decreased by $83.18 \%$ with Nile water. It is evident that, applying the treated sewage water caused a biological harm due to the great number of coliform that lives on leaves and it was extremely greater than that caused by the Nile water.

\section{Table (7): Concentration of the total coliform density and fecal coliform Count on Bermuda leaves with Nile and treated sewage water.}

\begin{tabular}{|c|c|c|c|c|c|c|}
\hline \multirow{2}{*}{ Elements } & \multicolumn{2}{|c|}{ Before applying water } & \multicolumn{2}{|c|}{ After applying water } & \multicolumn{2}{|c|}{ Changing (\%) percent } \\
\hline & $\begin{array}{c}\text { Treated } \\
\text { sewage water }\end{array}$ & Nile water & $\begin{array}{c}\text { Treated } \\
\text { sewage water }\end{array}$ & Nile water & $\begin{array}{c}\text { Treated } \\
\text { sewage water }\end{array}$ & $\begin{array}{l}\text { Nile } \\
\text { water }\end{array}$ \\
\hline $\begin{array}{c}\text { Total coliform } \\
\text { density TCD } \\
(\mathrm{mg} / \mathrm{kg})\end{array}$ & $1.2 \times 10^{5}$ & $227 \times 10^{3}$ & $12 \times 10^{5}$ & $250 \times 10^{3}$ & 900 & 10.13 \\
\hline $\begin{array}{c}\text { Fecal coliform } \\
\text { count FCC }\end{array}$ & $0.07 \times 10^{5}$ & $107 \times 10^{3}$ & $0.7 \times 10^{5}$ & $18 \times 10^{3}$ & 900 & -83.18 \\
\hline
\end{tabular}




\section{REFERANCES}

Asano, T. (Ed), 1998, Water Quality Management/ Library. Volume 10/, Wastewater Reclamation and Reuse. Technomic Publishing Company, Inc Lancaster, Pennsylvania, U.S.A

Ayers, R.S. and Westcot D.w., 1985,. Water Quality for Agriculture. Rev.Edn. FAO, Irrig. and Drain. Paper 29 Rome 174pp.

Darwish, M.R., El-Awar, F.A., Sharara, M. and Hamdar, B. 1999, EconomicEnvironmental Approach for Optimum Wastewater Utilization in Irrigation: A Case Study in Lebanon. Applied Engineering

El-Sayed, A., 1997. Water Quality Management of Drainage Systems in Eastern Nile, Delta. Ph.D. Thesis, Ain Shams University, Cairo, Egypt.

FAO, 1992, Wastewater Treatment and Uuse in Agriculture. Pescod Mb, Irrigation and Drainage Paper 47. Food and Agriculture Organization, Rome, Italy.

Martijn, E.J. and Huibers F.P., 2001, Use of Treated Wastewater in Irrigated Agriculture: A design Framework Development of Cost-Effective Reclamation Technologies for Domestic Wastewater and the Appropriate Agricultural Use of the Treated Effluent under semi-Arid Climate Conditions (CORETECH) Working, Document, WP4-3. Wageningen, Netherlands, $33 \mathrm{pp}$.

Pescod, M.B., 1992, Wastewater Treatment and Use in Agriculture. University of Newcastle- Upon- Tyne, UK, FAO irrigation and Drainage Paper No.47

Shelef, G. 1977, Water Reuse in Israel. In: Shuval Hi (Ed), Water renovation and reuse, Academic Press. New York, pp: 311-332

Sheikh, B., Cort, R., Cooper, R.C., and Jaques, R.S., 1998, Tertiary Treated Reclaimed water for irrigation of Raw Eaten Vegetables. In: Asano T (ed), (1998) pp; 779-826.

Shuval, H.I., Adin, A., Faattal, B., Rawitz, E. and Yekutiel, P., 1986, Wastewater Irrigation in Developing Countries. Health Effect and Technical Solutions. World Bank Tech. Paper 51, 324 pp. 


\section{الملخص العربى}

\section{أداء نظم ري المسطحات الخضراء تحت ظروف مياه الصرف الصحي المعالج}

د. ياسر محمد محروس عطا؟

د. محمد علي أبوعميره' د. أحمد حسن جمعه'

أجريت هذه الدر اسة بالمزر عة التجريبية للمركز القومي لبحوث المياه والملحق بها محطة معالجة

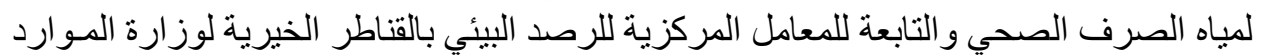
المائية و الرى بجمهورية مصر العربية.

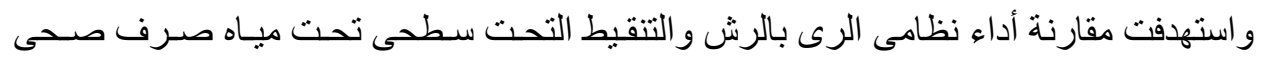

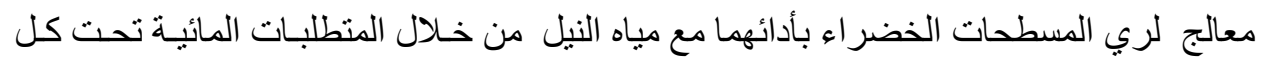

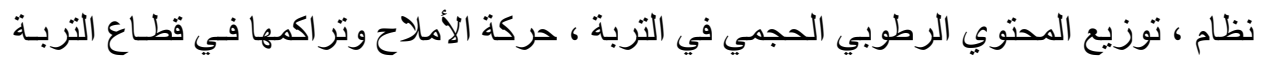

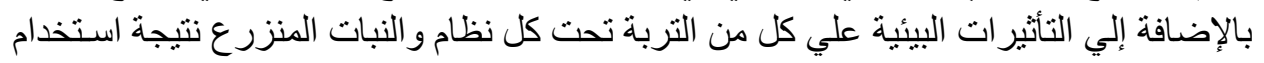
مياه صرف صحي معالج تحت كل نظام.

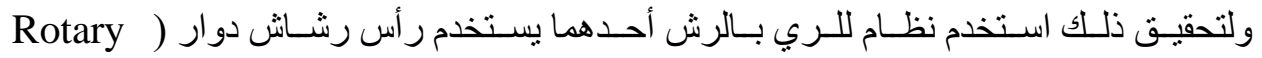
Spray (sprinkler head (sprinkler head

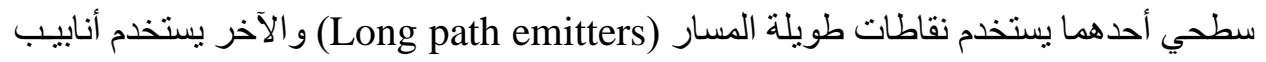

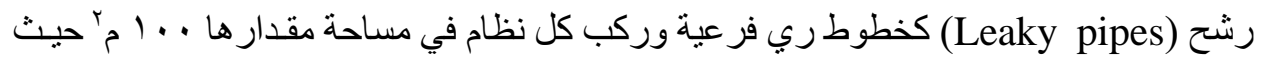
كانت محطة معالجة مياه الصرف الصحي هي المصدر الرئيسي لمياه الصرف الصـي الصحي المعـالج

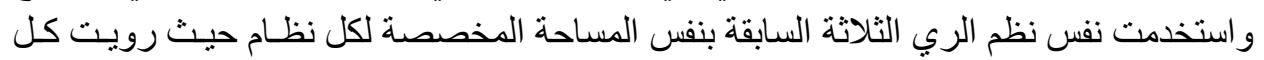
مساحة بمياه النيل واستخدم برنامج CROPWAT لحساب قيمة البخر نتح المرجعي في أرض لفر التجربة. وتوصلت الدر اسة إلي النتائج الآتية:

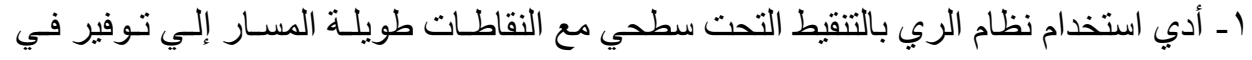

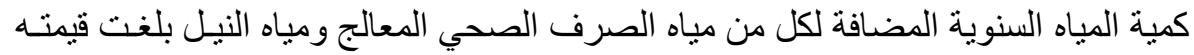

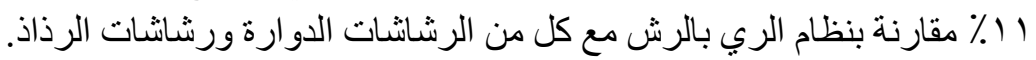

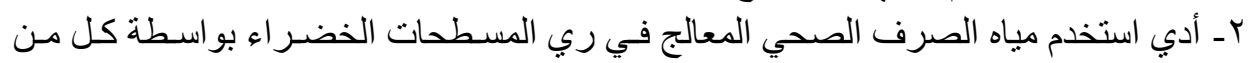

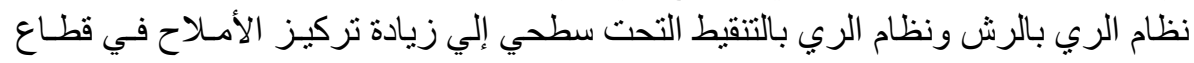

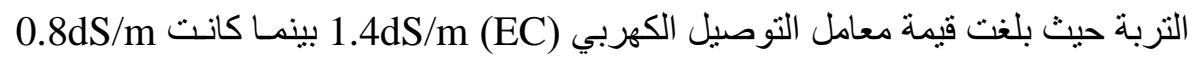

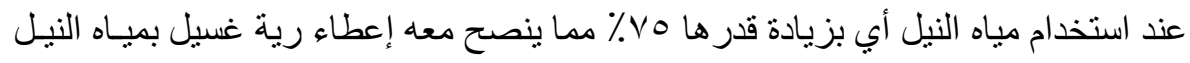

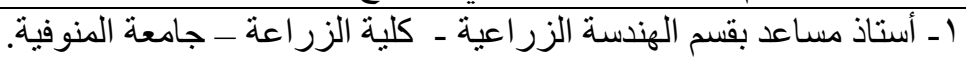

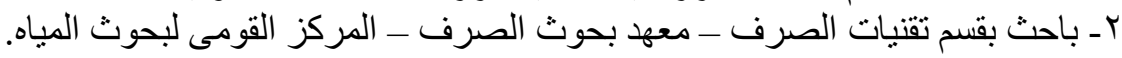




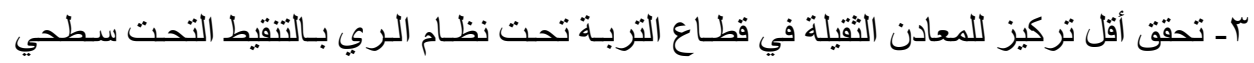

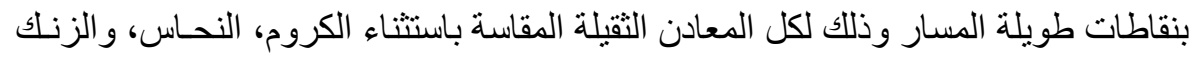
فى حالة إستخدام مياه الصرف الصنار وذلف الصحى المعالج.

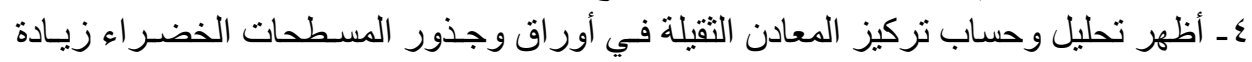

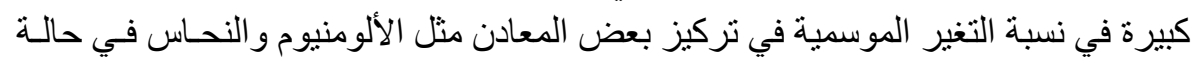

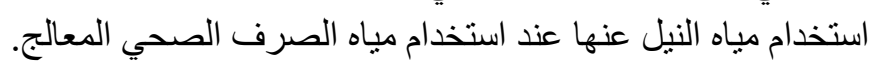

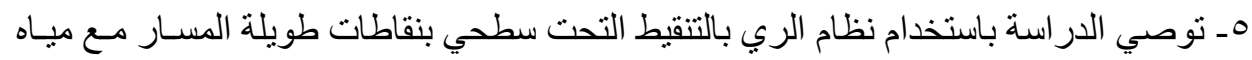

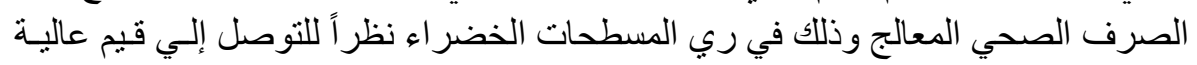

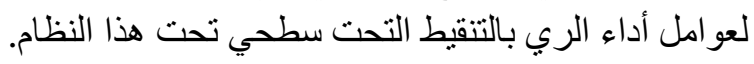

